INDEPENDENT JOURNAL OF MANAGEMENT \& PRODUCTION (IJM\&P)

http://www.ijmp.jor.br

v. 12, n. 1, January-February 2021

ISSN: 2236-269X

DOI: 10.14807/ijmp.v12i1.1238

\title{
SUSTAINABLE SUPPLY CHAIN MANAGEMENT DRIVERS AND OUTCOMES: AN EMPHASIS ON STRATEGIC SUSTAINABILITY ORIENTATION IN THE FOOD INDUSTRIES
}

\author{
Korosh Emamisaleh \\ Department of Industrial Management, Islamic Azad University South \\ Tehran Branch, Iran \\ E-mail: k.emamisaleh@gmail.com
}

Arshia Taimouri Department of Management, University of Ershad Damavand, Iran E-mail: arshiateimouri@gmail.com

Submission: $1 / 6 / 2020$

Revision: 2/2/2020

Accept: 3/9/2020

\section{ABSTRACT}

Nowadays, due to the quick increase of population, degradation of the environment and social disparity moving towards sustainability is an indispensable issue. Aside from this importance, paying attention to sustainability provides opportunities for firms to be innovative. Previous studies largely focused on identifying drivers that enhance the firm capacity to innovate new products and services. However, less attention has been paid to sustainability orientation as a direct driver of a firm's innovativeness leading towards long term business performance. In this study, sustainable supply chain drivers, strategic sustainability orientation and firm performance have been evaluated. The mediating concepts such as corporate environmental management and corporate social responsibility impacting the relationship between strategic sustainability orientation and firm performance have been tested too. The results illustrate that employees' motivation and managerial attitude have positive impacts on strategic sustainability orientation and on the other hand strategic sustainability orientation with the mediating roles of corporate environmental management and corporate social responsibility has a positive effect on firm performance. This study was conducted on 120 Iranian companies that are active in food industries by using the SEM method. 
DOI: 10.14807/ijmp.v12i1.1238

Keywords: Sustainable supply chain management; Strategic sustainability orientation; Supply chain management; Sustainability; drivers; Iranian food industries

\section{INTRODUCTION}

These days, in order to address the challenges attributed to the rapid increment of population, degradation of the environment and social disparity, sustainable development and specifically sustainable manufacturing are gaining considerable importance (Ahmad et al, 2018; Waas et al., 2014).

To date, sustainable development has been defined in different ways but the most prominent definition was presented in the Brundtland Report of the World Commission on Environment and Development as " the development that meets the needs of the present without compromising the ability of future generations to meet their own needs” (World Commission on Environment and Development, 1987).

Veleva and Ellenbecker, (2001) stated that most of the industries commenced applying sustainable development practices and defined it as "the creation of goods and services using processes and systems that are non-polluting, conserve energy and natural resources, are economically viable, safe and healthy for employees, communities, and consumers, socially and creatively rewarding for all working people.”

In the scope of manufacturing, the main goal of sustainable development is to generate manufacturing systems and functions being able to realize the requirements of three dimensions of sustainability Elkington, (1999), including economic (profit), ecological (planet) and social (people) (Shrivastava \& Berger, 2010). In the twenty-first century, Sustainable development has become a principal concept in the supply chain of firms.

According to a definition of supply chain management (SCM), which is "the management of trading-off materials and information in the logistics process of companies ranging from raw materials’ procurement to delivery to the customers”, the supply chain of a company involves a substantial number of suppliers, producers along with customers and undoubtedly being responsive to the challenges of supply chain and subsequently its attribution to the environment and society are one of the significant issues in the SCM area.

In this situation, when the SCM attempts to respond to the three subjects of society, economy, and environment, the main concepts of the sustainable supply chain are being formed (Emamisaleh \& Rahmani, 2017). In fact, the sustainable supply chain management could be 
DOI: 10.14807/ijmp.v12i1.1238

defined as "integration of social, economic, and environmental practices within a global supply chain that provides green products, excellent services, and accurate information” (Xie \& Allen, 2013).

This field of research (sustainability in the supply chain) has been investigated from multifarious dimensions over the last years (Beske, Land \& Seuring, 2014). Also, for the time being, companies are being impacted by various factors, namely the governments, community, stakeholders, customers, employees along with suppliers to apply sustainable supply chain initiatives Constantly (Hassini, Surti \& Searcy, 2012; Hsu et al., 2013; Varsei et al., 2014).

In the literature, these factors have been defined identically by different names such as drivers, enablers, triggers, and pressures (Caniato et al., 2012; Hsu et al., 2013; Köksal et al., 2017). Drivers play a fundamental role both in development and tendency towards the sustainable supply chain. In the literature, there are multiple practices for implementing sustainable supply chain management.

In this research, we emphasize on strategic sustainability orientation, corporate environmental management, and corporate social responsibility. In strategic orientation practice, the strategic values of a firm are demonstrated. Those companies following the sustainability strategies, consider equal importance on the three dimensions of sustainability for decision making and are usually guided by the Triple Bottom Line (Beske et al., 2014; Dyllick \& Hockerts, 2002; Gimenez, Sierra \& Rodon, 2012; Nikolaou, Ierapetritis \& Tsagarakis, 2011).

Triple Bottom Line concept (TBL) is explained as: "simultaneously considering and balancing economic, environmental and social goals from a business point of view" (Elkington, 1994). Corporate environmental management is about implementing a specific set of programs and schedules through improving the environmental performance of the supply chain ( Wu et al., 2017).

In addition, there are several definitions in the literature for corporate social responsibility. One of these definitions is described as "situations where the firm goes beyond compliance and engages in actions that appear to further some social good, beyond the interests of the firm and that which is required by law" (McWilliams, Siegel \& Wright, 2006).

On the other hand, due to the rapid growth of world population and the burgeoning request for consumer goods, manufacturing industries have undergone a dramatic pressure 
INDEPENDENT JOURNAL OF MANAGEMENT \& PRODUCTION (IJM\&P)

http://www.ijmp.jor.br

v. 12, n. 1, January-February 2021

ISSN: 2236-269X

DOI: 10.14807/ijmp.v12i1.1238

during the last years. In order to cope with the aforementioned demands, additional industries have emerged and more products have been promoted to the markets.

Therefore, aside from the significant impacts on the society and economy, it is completely evident that manufacturing industries consume a substantial amount of energy and natural resources (Linke et al., 2013) and subsequently release detrimental emissions to the air and land. In addition, the harmful effects of manufacturing operations on human life and ecosystem should not be taken for granted.

The problems derived from these effects incorporate human health, soil biodiversity, desertification, water pollution, and food safety. Contrary to the past that the majority of research concentrated solely on increasing the efficacy and curbing costs of manufacturing industries (Mohanty \& Prakash, 2017), currently and following the raised awareness regarding the sustainability-related issues, such as global warming and climate change, monitoring and reducing the social and environmental impacts have become a serious issue in manufacturingrelated research (Allen et al., 2002; Haapala et al., 2013).

Particularly, sustainable development is an imperative issue among food industry companies. Primarily, food-producing companies are regularly forced to balance their business performance and economic achievements with social and environmental performance. Besides, due to some reasons including population growth, changes in our nutritional habits and increasing economic incomes (Tilman et al., 2002) global food consumption has experienced a dramatic enhancement.

This growing consumption has transparent consequences: increased demand, production and distribution of food in the world leading to critical environmental, social and economic problems (Tilman et al., 2002). Hence, in the current condition of food industries in the world, sustainable development plays a key role. Iran, as one of the largest countries in the Middle-East, attempts to achieve sustainable economic growth by developing the food industries and agricultural products.

Food industries' products in Iran are related to agriculture, Animal husbandry, and fishing. According to a report published by Statistical Center of Iran (SCI) in 2008, food industries ranked first and third regarding the recruitment of workforce and added value respectively indicating the high potential of this industry for economic development in Iran.

The main purposes of this study are distributed into three phases. In the first phase of this study, the impacts of the drivers of adopting sustainability, involving mimetic, coercive 
DOI: 10.14807/ijmp.v12i1.1238

and normative pressures, managerial attitude and employees' motivation on tendencies towards sustainability strategies in Iran's food industries are investigated. In the second phase, the interactions between three practices of sustainable supply chain management, namely strategic sustainability orientation, corporate social responsibility, and corporate environmental management are examined.

Finally, by reviewing the literature it is obvious that previous researchers neglected to assess the effects of sustainable supply chain management practices on firm performance profoundly. However, in this paper, the effects of these practices on firm performance are evaluated. Moreover, having observed the precious benefits of sustainable supply chain strategies, it is aimed at encouraging the managers of food industries to adopt this valuable concept. Eventually, in this article we endeavor to answer the following questions:

1) What are the drivers of sustainable supply chain management in the food industry of Iran?

2) What are the relationships between the three practices of sustainable supply chain management (strategic sustainability orientation, corporate social responsibility, and corporate environmental management) regarding the food industry of Iran?

3) What are the outcomes of sustainable supply chain management or its effects on firm performance?

Accordingly, in order to answer the research questions and achieve the determined goals, the following research procedure was planned: 1)Reviewing the literature to design the research conceptual model 2)Providing the research hypotheses based on the conceptual model 3)Designing the research questionnaire according to the variables of conceptual model as well as research hypotheses 4)Gathering the required data and assigning the sample and statistical society 5)Testing the research hypotheses based on Structural equation modeling method and 6)Analyzing the results and providing the conclusions and managerial implications.

\section{LITERATURE REVIEW}

\subsection{Sustainable supply chain drivers}

Nowadays, moving toward sustainability is essential. Whether manufacturing organizations prefer or not, due to the existence of drivers and pressures derived from the environment forcing them to follow the sustainability standards, they must be committed to sustainable thinking ( Emamisaleh \& Rahmani, 2017). 
DOI: 10.14807/ijmp.v12i1.1238

The institutional theory explains how external pressures impact an enterprise (DiMaggio \& Powell, 1983). Drawing upon this theory, the categorization of environmental pressures is based on the following sequence: Regulatory (regulation and law), Normative (from the market) and Cultural-Cognitive which are internal pressures (Jia et al., 2018).

The drivers which affect the firms are explored according to the Institutional theory and resource-based view. Resource-based view is a managerial framework that is employed to determine the strategic resources of a firm, containing capabilities and assets, organizational culture, attributes, information and the knowledge enabling it to attain sustainable competitive advantage (Resource-based view 2019).

There are a large number of sustainability enablers in the literature (Seuring \& Müller, 2008). In addition, scholars have categorized these initiatives in different ways so far. However, in this study, Coercive, Mimetic and Normative pressures, as well as Managerial attitude and employees’ motivation, are considered as affecting drivers.

Coercive drivers pertain to the rules and regulations stipulated by organizations that are active in the field of sustainability and the governments forcing or encouraging enterprises to consider sustainability into high consideration. Mimetic drivers are related to the market conditions and adaptability of companies to these conditions. In fact, mimetic drivers happen when a company is forced to imitate its competitor's successful performance and business model based on the market status.

Besides, normative drivers are attributed to the expectations of society and organizations, including NGOs, trade unions and local communities of consumers which their main concern is sustainability (Emamisaleh \& Rahmani, 2017). On the other hand, the roles of top management and employees are imperative with respect to moving towards sustainability which has been regularly investigated by the previous studies (Defee, Esper \& Mollenkopf, 2009; McFadden, Henagan \& Gowen, 2009; Reed, 2002a). A top manager is the main reason and initiative for the majority of organizational activities (Defee et al., 2009).

Most of the researchers are of the opinion that the commencement and successful execution of any change in an organization are positively correlated to the view and attitude of managers. In this regard, for acquiring a successful implementation of sustainability in an organization the culture of that organization should be changed (Harris \& Crane, 2002). Therefore, the attitude of top management could be a critical success factor in moving towards sustainability (Defee et al., 2009). 
DOI: 10.14807/ijmp.v12i1.1238

The culture of need for alteration to implement sustainable development practices is institutionalized in the culture of an enterprise when the top managers adopt a committed, positive and active opinion about sustainability ( Emamisaleh \& Rahmani, 2017). It should be mentioned that this attitude is constructed when top managers do not consider sustainability as a risk or threat to their organization (Aragón-Correa \& Sharma, 2003).

In addition to the role of top management, the motivation of staff for implementing sustainability strategies is an indispensable issue. In order to experience an efficient employee engagement, top managers should encourage and support them constantly. The more the employees are convinced to pursue the measures of sustainability implementation, the more they are motivated to adopt these measures and subsequently their role in developing sustainability is significant (Daily \& Huang, 2001; Reed, 2002b).

\subsection{Strategic Sustainability Orientation}

Sustainability orientation has been defined in different ways in the literature. Claudy, Peterson and Pagell, (2016) defined it as "the extent to which firms are actively integrating sustainability principles into their business purpose”. These principles include strategies pertained to the environment (Jin, Navare \& Lynch, 2018).

The construct of orientation concept fundamentally refers to a strategic focus that is determined within an organization as the organizational culture (Claudy et al., 2016). Another definition was presented by (Roxas \& Coetzer, 2012). They defined sustainability orientation as "the overall proactive strategic stance of firms towards the integration of environmental [and social] concerns and practices into their strategic, tactical and operational activities”. From this definition, it is evident that sustainability orientation demonstrates itself in organizational culture and strategic structures, allowing companies to integrate sustainability issues and concerns in their operational programs (Banerjee, 2002; Fraj-Andrés, Martinez-Salinas, \& Matute-Vallejo, 2008).

Pagell and Wu, (2009) defined strategic sustainability orientation as "the active and committed decision-making of an organization and its whole supply chain about the economic, social and environmental issues” ( Emamisaleh \& Rahmani, 2017). By investigating this definition profoundly, some points are concluded; (a) attaining economic, social and environmental targets, (b) adopting a sustainable attitude towards resources that are suitable for social and environmental goals, (c) the existence of sustainability concepts in the all layers of an organization, including discourses, practices, and decisions, (d) sustainability values and 


\section{INDEPENDENT JOURNAL OF MANAGEMENT \& PRODUCTION (IJM\&P)}

http://www.ijmp.jor.br

v. 12, n. 1, January-February 2021

ISSN: 2236-269X

DOI: 10.14807/ijmp.v12i1.1238

beliefs have to be executed in a modern way in the organization's business model and (e) all members of an organization are responsive to the issues and concerns of sustainability and a particular organization or part of its supply chain are not excluded.

Generally, strategic sustainability orientation illustrates how sustainability factors and issues are executed and performed at an organization. The orientations of strategic sustainability are explained in economic, social and environmental scopes (Baumgartner \& Rauter, 2017). The economic orientation of strategic sustainability is an attempt to develop technology and innovation in an organization leading to producing clean products that are compatible with the conditions of the environment.

Other factors, such as knowledge management, collaboration and participation in the process of sustainability and publishing sustainability reports are considered as other economic strategies of sustainability. Generally speaking, sustainable economic orientation is related to an active commitment of an organization to notice sustainability issues in financial decisions and markets, decisions that are attributed to manufacturing and the ways in which resources are used for manufacturing (Kroes \& Ghosh, 2010).

According to the opinions of Baumgartner, (2010) sustainable social orientation includes internal and external orientations. He believes internal strategies consist of staff safety, organizational rules, and justice, considering employees in the decision-making process and the maintenance of customer information. In addition, he defines external strategies as the involvement of organizations in cultural and social ceremonies, being responsive to the rights of society and customers, supplying appropriate and accurate information for the customers and addressing the requirements of the society.

And finally, Baumgartner and Rauter, (2017) consider the sustainable environmental orientation as a process having specific inputs and outputs. The inputs are raw materials that are recyclable and returnable to the environment and on the other hand, the outputs are products and services which are environmentally clean, meaning that they are harmless to the environment and do not put the lifecycle of animals and plants in danger. To sum up, we can conclude that sustainability orientation is made out of practices for developing health and safety, protecting the environment and ecosystem and solving the end-of-product-life recycling problems (Bloemhof-Ruwaard et al., 1996; Guide, 2000; Karakayali, Emir-Farinas \& Akcali, 2007). Therefore, strategic sustainability orientation is a golden key for organizations in order to be prosperous (Laudal, 2011). 
DOI: 10.14807/ijmp.v12i1.1238

\subsection{Corporate Social Responsibility and Corporate Environmental Management}

\subsubsection{Corporate Social Responsibility}

Over the last few decades, the continuing discussions with respect to the appropriate relationships between the business and society have resulted in the generation of corporate social responsibility concepts (Schwartz \& Carroll, 2003). The core idea behind the corporate social responsibility (CSR) is that a business not only should be responsible for its tasks towards shareholders, employees, suppliers, and customers but also should go beyond and be accountable for all the non-economic results of its activities regarding the wider society as well as the natural environment (Robins, 2005).

Corporate social responsibility (CSR) is not a novel concept, it has been discussed for more than half a century in the management literature (Bowen, 1953). In addition, by reviewing the literature, numerous definitions for CSR are available. In a comprehensive study, and after analyzing 37 definitions, Dahlsrud, (2008) determined the five particular dimensions of corporate social responsibility, including social, voluntariness, stakeholders, environmental and economics.

One of the most prominent and widely used definitions of CSR was submitted by the Commission of the European Communities as "a concept that companies use as means to integrate social and environmental issues in their business operations and in their interaction with their stakeholders on a voluntary basis”. Besides, Holme, Watts, \& World Business Council for Sustainable Development, (2000) defined the CSR as “continuing commitment by business to behave ethically and contribute to economic development while improving the quality of life of the workforce and their families as well as the local community and society at large”.

\subsubsection{Corporate Environmental Management}

These days, due to the existence of some reasons such as the pressure of consumers, potential cost savings, laws and ethics; companies have understood that environmental issues should be solved. Environmental management is a systematic approach for finding pragmatic ways in order to save water, energy, materials and mitigate negative environmental effects.

In other words, environmental management is determined to improve the level of sustainable development implementation while taking in to account the environmental issues, namely the damages imposed to natural resources and environmental pollution, derived from the services and manufacturing activities (Gray \& Bebbington, 2001; North, 1997). 
DOI: 10.14807/ijmp.v12i1.1238

Klassen and McLaughlin, (1996) believe that the long-term target of environmental management is "considering environmental aspects in an integrated fashion in product design, the entire manufacturing process, marketing, product delivery and use, consumer service, and post-consumer product disposition”. Paying attention to environmental management has several benefits for companies.

For example, by participating in environmental management and having an active attitude towards society and the environment, companies are able to enhance profitability and create competitive advantage (Berry \& Rondinelli, 1998; Christmann, 2000; Porter \& van der Linde, 1995). Besides, responding to various stakeholders demanding corporate social responsibility is another advantage of joining environmental management.

Parallel to the issue of environmental management, corporate sustainability management is a concept referring to management attempts and activities that advocates sustainable growth and increased corporate values (Bansal, 2005). Hence, environmental sustainability is a prerequisite for attaining corporate sustainability management (Goodland, 1995) and environmental management is a notable strategy for running corporate sustainability management. (Kim \& Kim, 2019).

\section{CONCEPTUAL FRAMEWORK AND HYPOTHESES DEVELOPMENT}

According to the concepts of sustainable supply chain drivers, strategic sustainability orientation, corporate social responsibility, and corporate environmental management and their overall impacts on firm performance explained in the previous sections, the conceptual model of this paper is presented (Figure 1).

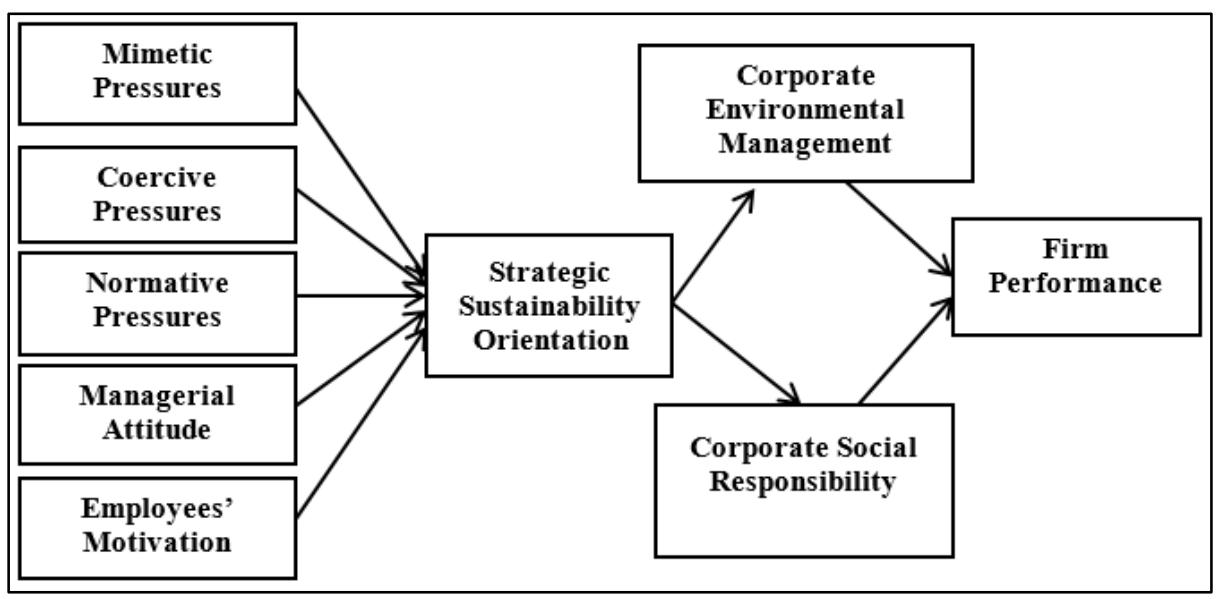

Figure 1: Conceptual Model 
DOI: 10.14807/ijmp.v12i1.1238

According to the conceptual model of this paper and for developing the hypotheses, previous studies are investigated as follows: 1- Relationship between Sustainable supply chain drivers and strategic sustainability orientation. 2- Relationship between strategic sustainability orientation and firm operational performance while considering corporate social responsibility and corporate environmental management as mediating factors.

\subsection{Relationship between Sustainable supply chain drivers and strategic sustainability orientation}

Engert, Rauter and Baumgartner, (2016) reviewed 114 published papers in scientific journals to examine the concepts of drivers and organizational factors. Based on this study, it is concluded that the drivers of the sustainable supply chain can be connected to the strategic sustainability orientation. Figure 2 demonstrates this model which is an appropriate basis for the conceptual model of this study.

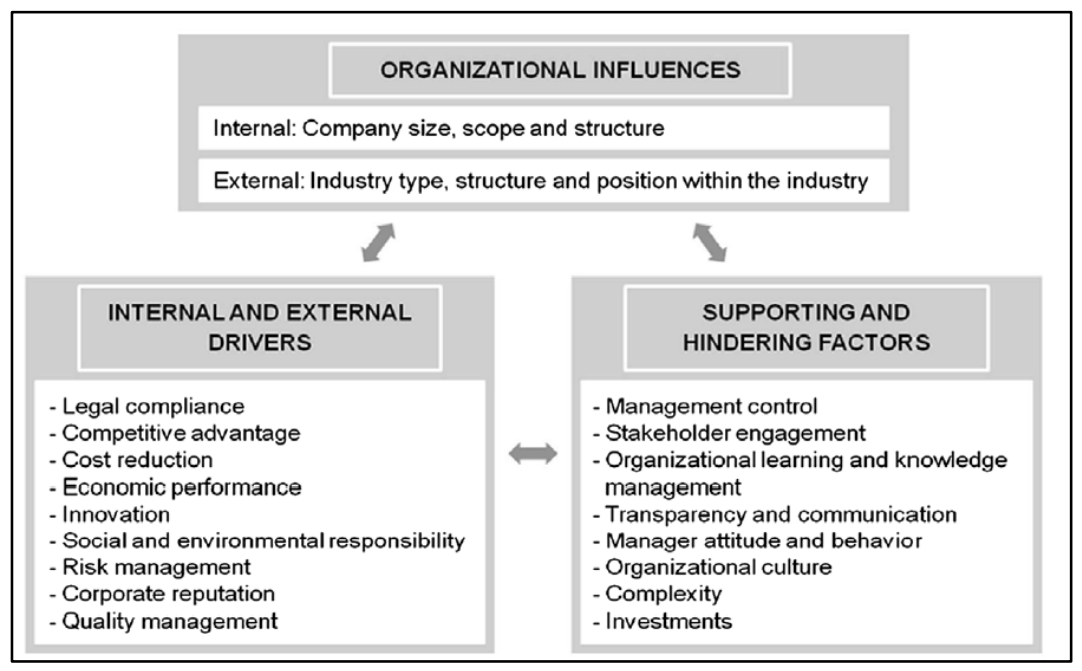

Figure 2: Integrating corporate sustainability into strategic management Source: Engert et al. (2016)

As mentioned in previous sections, Managerial attitude is one of the considered drivers of implementing sustainable supply chain management. The study of Campbell, (2000) revealed that in a company to a large extent the attitude and support of top management define the actions. Besides, Signori et al., (2015) believe that managers' attitude to the issue of sustainability is an important factor with respect to implementing sustainability strategies successfully.

In this respect, Green, et al. (2012) contend that in constituting the sustainability strategies, the activities and the supportive behavior of managers within the enterprise are impressive. Implementing sustainability strategies also enhance the competitiveness power of 
DOI: 10.14807/ijmp.v12i1.1238

organizations and generate proper business opportunities. In order to achieve a sustainable organization, the existence of sustainable strategic planning is essential and strategic sustainability must be expanded.

Furthermore, staff motivation plays a key role to have sustainability strategies implemented successfully (Emamisaleh \& Rahmani, 2017). In a paper conducted by Chan, et al. (2012), the conception of employees about the significance of sustainability issues, staff motivation, and top management support are introduced as drivers which have major impacts on the sustainable performance of an organization. In another study, the role of involvement and staff motivation in the sustainable processes of an enterprise was explored more meticulously.

The researchers in this study demonstrated that staff involvement in sustainability issues contributes to the improvement of firm performance in the scopes of the environment as well as operations and as a result, this brings about the successful implementation of sustainability objectives and strategies in an organization (Hanna, Newman \& Johnson, 2000). Hence, it is hypothesized that:

- $\mathrm{H}_{1}=$ Employees' motivation has a positive impact on strategic sustainability orientation

- $\mathrm{H}_{2}=$ Managerial attitude has a positive impact on strategic sustainability orientation

On the other hand, while Delmas and Toffel, (2004) concluded that factors such as competitors, governmental regulations and trading partners contribute to the creation of environmental-based strategies, Tachizawa et al., (2015) showed that customers, society, supply chain suppliers, and local organizations are the main external factors in this regard.

In addition, Kudłak, (2017) considered drivers namely, brand image, the expectations of society, local enterprises and the requirements of the suppliers as external drivers for implementing sustainability strategies successfully. Related to this issue, Roehrich, Hoejmose and Overland, (2017) assert that the following drivers: 1-competitors 2-vendors 3-customers and 4-existing regulations and guidelines play a key role with respect to executing sustainability strategies.

According to a study, vendors, suppliers and the involvement of governmental agencies are external drivers affecting the decisions of organizations to take part in sustainable activities (Lee, 2008). In another research, Teo et al., (2003) introduced normative, coercive and mimetic drivers as external drivers that impact the interaction of an organization with the environment. 
DOI: 10.14807/ijmp.v12i1.1238

Finally, Liu et al., (2010) believe that external drivers, including mimetic, normative and coercive ones assist an organization to constitute orientation towards sustainable supply chain management. Therefore, based on the aforementioned material it is hypothesized that:

- $\mathrm{H}_{3}=$ Normative pressures have a positive impact on strategic sustainability orientation

- $\mathrm{H}_{4}=$ Coercive pressures have a positive impact on strategic sustainability orientation

- $\mathrm{H}_{5}=$ Mimetic pressures have a positive impact on strategic sustainability orientation

\subsection{Relationship between strategic sustainability orientation and firm operational performance}

Despite a plethora of research investigating the relationship between the strategic sustainability orientation and firm performance have been done, a small number of researchers have focused on the mediating factors affecting this relationship. In this study, corporate social responsibility and corporate environmental management are considered as mediating factors. However, in the literature papers studied this relationship by considering various mediating and moderating factors.

Danso et al. (2019) introduced competitive strategies, including low cost, differentiation, and integration as moderators impacting the environmental sustainability orientation (ESO)-performance relationship. This study had two main results. Firstly, they found that the differentiation strategy is able to positively enhance the ESO performance outcomes. Secondly, firms can employ ESO along with low-cost and integrated strategies in order to improve their performance.

In another study conducted by Feng et al. (2019), the researchers evaluated the relationship between customer orientation (CO) and firm performance while considering ethical leadership (involving justice leadership, humane leadership and moderation leadership) and competitive intensity as moderating factors. They concluded that humane leadership along with moderation leadership help organizations to utilize customer orientation for enhancing their performance.

In addition, they found that companies that are operating in a less competitive environment should not take moderation leadership for granted and justice leadership help firms to perceive the advantages of $\mathrm{CO}$ while providing positive impacts for them. In a research carried out by Croom et al. (2018) the impact of social sustainability orientation on operational 
INDEPENDENT JOURNAL OF MANAGEMENT \& PRODUCTION (IJM\&P)

http://www.ijmp.jor.br

v. 12, n. 1, January-February 2021

ISSN: 2236-269X

DOI: 10.14807/ijmp.v12i1.1238

performance by considering basic and advanced Socially sustainable supply chain(SSSC) practices as mediating factors and long term orientation as moderating factor was appraised.

They concluded that operational performance is predictable by sustainability orientation when SSSC practices are implemented in an advanced but not basic form. Moreover, their results indicated that the relationship between sustainability orientation and operational performance is dramatically moderated by long term orientation factor. Mediating factors are various in the literature.

For instance; Sustainable procurement and design are determined as mediating factors in the study of Shashi et al. (2018) and finally their effects on environmental and cost performance of SMEs are examined. Their findings show that 1) sustainability orientation influences both sustainable procurement and design in a positive way. 2) The impacts of sustainable procurement on environmental and cost performance are positive and neutral respectively, 3) sustainable design influences both cost and environmental performance positively. In this regard, Koo, Chung and Ryoo, (2014) examined the mediating effects of coordination on environmental sustainability orientation and environmental performance relationship.

The results demonstrate that this relationship is mediated by green manufacturing coordination and green supply chain coordination. Sayem, (2012) took sustainability orientation into account as the driver of firm innovativeness, including organizational and technological innovations. Finally and exceptionally, some research, such as one conducted by (Eijdenberg, Sabokwigina \& Masurel, (2019) showed that environmental sustainability orientation minimally impacts the firm's performance.

On the other hand, a substantial number of researchers have investigated the relationship between corporate social responsibility and firm performance, so that the majority of them confirm the positive impact of corporate social responsibility on firm performance (Agyemang \& Ansong, 2017; Amini \& Bianco, 2017; Janamrung \& Issarawornrawanich, 2015; Liu \& Lu, 2019; Makanyeza, Chitambara \& Kakava, 2018; Maqbool \& Zameer, 2018; Martinez-Conesa, Soto-Acosta \& Palacios-Manzano, 2017; Sial et al., 2018; Wang et al., 2012; Youn, Hua \& Lee, 2015).

In addition, so far several research have concluded that corporate environmental management practices, such as $\mathrm{CO}_{2}$ and waste emissions and environmental research and development influence firm performance positively (Ann, Zailani \& Wahid, 2006; 
DOI: 10.14807/ijmp.v12i1.1238

Burgos-Jiménez et al., 2013; Iwata \& Okada, 2011; Nishitani et al., 2017; Solovida \& Latan, 2017). Hence, the following hypotheses are developed:

- $\mathrm{H}_{6}=$ strategic sustainability orientation with the mediating role of corporate environmental management has a positive impact on firm performance

- $\mathrm{H}_{7}=$ strategic sustainability orientation with the mediating role of corporate social responsibility has a positive impact on firm performance

\section{RESEARCH METHOD}

\subsection{Sample and procedure}

In this research, the statistical society is all managers of Iranian food industry companies. By referring to the Information bank of Iranian food industry companies, generally, this industry in Iran is divided into the following categories: 1- Cereals (flour, chickpeas, wheat, corn, lentils) 2- Dairy products (milk and its derivatives) 3- Meat industries (livestock, poultry, aquatic food, eggs, canned) and Sugar and carbohydrates (sweets, chocolates, concentrates and sugary drinks).

The sample in this study contains 120 companies active in the four aforementioned sectors. Since in this article the issue of sustainability in the supply chain is under investigation, the factors of sustainability were studied in the chosen sample. All companies in this research own the ISO 9000, 14000 and 26000 certificates which are pertained to social responsibilities showing that all the chosen companies have taken the issue of sustainability into high consideration.

\subsection{Measurement}

In the current study, Mimetic, Coercive and Normative drivers are measured through 3,5 and 5 questions respectively. These questions are based on the studies of (Delmas \& Toffel, 2004; DiMaggio \& Powell, 1983; Liu et al., 2010; Teo et al., 2003). Besides, Managerial attitude and Employees' motivation drivers have been measured according to the previous studies. Managerial attitude is measured through four questions based on the Pagell and $\mathrm{Wu}$ (2009) and Sharma, (2000) studies. In addition, based on the studies of Daily and Huang, (2001), Hanna et al., (2000) and Reed, (2002b) employees' motivation is measured. Moreover, for evaluating the Strategic sustainability orientation, the studies of Defee et al., (2009), Kroes and Ghosh, (2010) and Pagell and Wu, (2009) are considered. 
DOI: 10.14807/ijmp.v12i1.1238

It is worth noticing that, the principle for evaluating the sustainability performance is the study of Kristal, Huang and Roth, (2010). In addition, another two variables, corporate social responsibility, and corporate environmental management are measured according to the research of Kim and Kim, (2019).

\subsection{Measurement model}

In this section, by using the conformity factor analysis (CFA) that results are demonstrated in Table 1, we have analyzed the measurement model. Since the values of Analysis of Variance Extracted (AVE) and Composite Reliability (CR) are larger than 0.5 and 0.7 respectively the convergent validity of the measurement model is admitted. Moreover, discriminant validity is evaluated in this research. The results of discriminant validity are gathered in Table 2 shows that the square root of the AVE for each construct is larger than the correlation level involving the constructs, which confirms the discriminant validity. Finally, and according to the findings, the measurement model fit is in the standard range.

Table 1: Measurement items

\begin{tabular}{|c|c|c|c|c|c|}
\hline Variables & items & $\begin{array}{l}\text { Factor } \\
\text { loading }\end{array}$ & $\begin{array}{l}\text { Composite } \\
\text { reliability }\end{array}$ & AVE & Alpha \\
\hline \multirow{5}{*}{$\begin{array}{l}\text { Normative } \\
\text { Pressures } \\
\text { (NOR) }\end{array}$} & NOR1 & 0.8094 & \multirow{5}{*}{0.890261} & \multirow{5}{*}{0.620916} & \multirow{5}{*}{0.848774} \\
\hline & NOR2 & 0.7131 & & & \\
\hline & NOR3 & 0.8746 & & & \\
\hline & NOR4 & 0.847 & & & \\
\hline & NOR5 & 0.6773 & & & \\
\hline \multirow{5}{*}{$\begin{array}{l}\quad \text { Coercive } \\
\text { Pressures } \\
\text { (COE) }\end{array}$} & COE1 & 0.7494 & \multirow{5}{*}{0.868796} & \multirow{5}{*}{0.570865} & \multirow{5}{*}{0.811684} \\
\hline & COE2 & 0.7393 & & & \\
\hline & COE3 & 0.7005 & & & \\
\hline & COE4 & 0.7309 & & & \\
\hline & COE5 & 0.8492 & & & \\
\hline \multirow{3}{*}{$\begin{array}{l}\text { Mimetic } \\
\text { Pressures } \\
\text { (MIN) }\end{array}$} & MIN1 & 0.8154 & \multirow{3}{*}{0.884386} & \multirow{3}{*}{0.718463} & \multirow{3}{*}{0.803159} \\
\hline & MIN2 & 0.8745 & & & \\
\hline & MIN3 & 0.8519 & & & \\
\hline \multirow{4}{*}{$\begin{array}{l}\text { Managerial } \\
\text { Attitude } \\
\text { (MAN) }\end{array}$} & MAN1 & 0.756 & \multirow{4}{*}{0.880858} & \multirow{4}{*}{0.650245} & \multirow{4}{*}{0.817492} \\
\hline & MAN2 & 0.887 & & & \\
\hline & MAN3 & 0.8381 & & & \\
\hline & MAN4 & 0.735 & & & \\
\hline \multirow{4}{*}{$\begin{array}{l}\text { Employees' } \\
\text { Motivation } \\
\text { (EMP) }\end{array}$} & EMP1 & 0.6532 & \multirow{4}{*}{0.86671} & \multirow{4}{*}{0.622318} & \multirow{4}{*}{0.790538} \\
\hline & EMP2 & 0.871 & & & \\
\hline & EMP3 & 0.8677 & & & \\
\hline & EMP4 & 0.7423 & & & \\
\hline & STE1 & 0.7485 & \multirow{2}{*}{0.911051} & \multirow{2}{*}{0.720129} & \multirow{2}{*}{0.862458} \\
\hline & STE2 & 0.8568 & & & \\
\hline
\end{tabular}


INDEPENDENT JOURNAL OF MANAGEMENT \& PRODUCTION (IJM\&P)

http://www.ijmp.jor.br

v. 12, n. 1, January-February 2021

ISSN: 2236-269X

DOI: 10.14807/ijmp.v12i1.1238

\begin{tabular}{|c|c|c|c|c|c|}
\hline \multirow{2}{*}{$\begin{array}{l}\text { Strategic } \\
\text { Sustainability } \\
\text { Orientation } \\
\text { (STE) }\end{array}$} & STE3 & 0.8765 & & & \\
\hline & STE4 & 0.9044 & & & \\
\hline \multirow{4}{*}{$\begin{array}{l}\text { Corporate } \\
\text { Environmental } \\
\text { Management } \\
\text { (CSR) }\end{array}$} & CSR1 & 0.8518 & \multirow{4}{*}{0.879944} & \multirow{4}{*}{0.650553} & \multirow{4}{*}{0.864154} \\
\hline & CSR2 & 0.9233 & & & \\
\hline & CSR3 & 0.6501 & & & \\
\hline & CSR4 & 0.7756 & & & \\
\hline \multirow{4}{*}{$\begin{array}{l}\text { Corporate } \\
\text { Environmental } \\
\text { Management } \\
\text { (ENV) }\end{array}$} & ENV1 & 0.4007 & \multirow{4}{*}{0.832528} & \multirow{4}{*}{0.570497} & \multirow{4}{*}{0.822235} \\
\hline & ENV2 & 0.8066 & & & \\
\hline & ENV3 & 0.8607 & & & \\
\hline & ENV4 & 0.8544 & & & \\
\hline \multirow{4}{*}{$\begin{array}{l}\text { Firm Performance } \\
\text { (PER) }\end{array}$} & PER1 & 0.6149 & \multirow{4}{*}{0.840159} & \multirow{4}{*}{0.571056} & \multirow{4}{*}{0.867427} \\
\hline & PER2 & 0.8364 & & & \\
\hline & PER3 & 0.7402 & & & \\
\hline & PER4 & 0.8116 & & & \\
\hline
\end{tabular}

Table 2: Correlation matrix

\begin{tabular}{|l|l|l|l|l|l|l|l|c|c|}
\hline \multicolumn{1}{|c|}{} & NOR & COE & MIN & MAN & EMP & STE & CSR & ENV & AVE \\
\hline NOR & 1 & & & & & & & & 0.890261 \\
\hline COE & 0.588 & 1 & & & & & & & 0.868796 \\
\hline MIN & 0.643 & 0.423 & 1 & & & & & & 0.884386 \\
\hline MAN & 0.442 & 0.394 & 0.386 & 1 & & & & & 0.880858 \\
\hline EMP & 0.482 & 0.429 & 0.445 & 0.764 & 1 & & & & 0.86671 \\
\hline STE & 0.516 & 0.434 & 0.452 & 0.867 & 0.78 & 1 & & & 0.911051 \\
\hline CSR & 0.911 & 0.513 & 0.502 & 0.397 & 0.447 & 0.518 & 1 & & 0.879944 \\
\hline ENV & 0.571 & 0.393 & 0.502 & 0.727 & 0.679 & 0.923 & 0.537 & 1 & 0.832528 \\
\hline PER & 0.637 & 0.46 & 0.479 & 0.817 & 0.729 & 0.928 & 0.584 & 0.623 & 0.840159 \\
\hline
\end{tabular}

\subsection{Structural model}

After analyzing the measurement model in this section, we will examine the research hypotheses by employing the structural model. This analysis is conducted by using the PLS software and its results are presented in Table 3. The results demonstrate that Employees' motivation has a positive impact on strategic sustainability orientation $(\mathrm{p}<0.05)$, hence $\mathrm{H}_{1}$ is supported. Moreover, we have found that Managerial attitude positively affects the strategic sustainability orientation either $(\mathrm{p}<0.05)$.

Therefore, $\mathrm{H}_{2}$ is supported too. On the other hand, there is no reason to admit the positive effects of Normative 'Coercive and Mimetic pressures on strategic sustainability orientation and accordingly, $\mathrm{H}_{3}, \mathrm{H}_{4}$, and $\mathrm{H}_{5}$ are not supported. As mentioned in the last sections, $\mathrm{H}_{6}$ investigates the mediating role of corporate environmental management and since the direct effect of strategic sustainability orientation on firm performance with the loading factor of 0.221 is approved and by considering that this loading factor is less than the result of 
DOI: 10.14807/ijmp.v12i1.1238

multiplying the path $(\mathrm{STE}->\mathrm{ENV})=0.923$ by $(\mathrm{ENV}->\mathrm{PER})=0.855$, so $\mathrm{H}_{6}$ is supported. Similarly, the results of analyzing the corporate social responsibility mediating role depicts that the direct effect of strategic sustainability orientation on firm performance with the loading factor of 0.221 is approved and given this loading factor is less than the result of multiplying the path $(\mathrm{STE}->\mathrm{CSR})=0.518$ by $(\mathrm{CSR}->\mathrm{PER})=0.523$, consequently $\mathrm{H}_{7}$ is supported.

Table 3. Structural model outputs

\begin{tabular}{|l|l|l|l|l|l|}
\hline \multicolumn{1}{|c|}{ path } & \multicolumn{1}{|c|}{$\begin{array}{c}\text { Entire } \\
\text { Sample } \\
\text { estimate }\end{array}$} & \multicolumn{1}{|c|}{$\begin{array}{c}\text { Mean of } \\
\text { subsamples }\end{array}$} & \multicolumn{1}{|c|}{$\begin{array}{c}\text { Standard } \\
\text { error }\end{array}$} & \multicolumn{1}{|c|}{ T-Statistic } & Result \\
\hline NOR->STE & 0.091 & 0.0992 & 0.0553 & 1.6462 & Not Support \\
\hline COE->STE & 0.016 & 0.034 & 0.0253 & 0.6329 & Not Support \\
\hline MIM->STE & 0.042 & 0.0514 & 0.033 & 1.274 & Not Support \\
\hline MAN->STE & 0.627 & 0.6333 & 0.0468 & 13.4025 & Support \\
\hline EMP->STE & 0.232 & 0.222 & 0.0562 & 4.126 & Support \\
\hline STE->CSR & 0.518 & 0.5237 & 0.0554 & 9.3518 & Support \\
\hline STE->ENV & 0.923 & 0.9263 & 0.0121 & 76.3025 & Support \\
\hline CSR->PER & 0.523 & 0.5124 & 0.0454 & 9.412 & Support \\
\hline ENV->PER & 0.855 & 0.8578 & 0.022 & 38.8529 & Support \\
\hline STE->PER & 0.221 & 0.202 & 0.0462 & 4.026 & Support \\
\hline
\end{tabular}

\section{DISCUSSION AND CONCLUSION}

\subsection{Discussion}

This paper inquires the drivers and outcomes of sustainable supply chain management by concentrating on strategic sustainability orientation. In the first phase of the research model, the impacts of drivers (Managerial attitude, Employees' motivation, and Coercive, Mimetic and Normative pressures) on strategic sustainability orientation are explored. The results revealed that Managerial attitudes and Employees' motivation both have positive effects on strategic sustainability orientation which are exactly consistent with the findings of previous studies.

For example, (Signori et al., 2015) concluded that the attitude of managers to sustainability issues is an important element for implementing sustainability strategies properly and accurately. Moreover, (Green et al., 2012) believe that for making sustainability strategies, the supportive behavior of managers is fundamental.

In addition, according to the study of Emamisaleh and Rahmani (2017), it is essential to pay special attention to staff motivation in order to implement sustainability strategies successfully. Besides, Chan et al., (2012) concluded that staff motivation along with top management support impact the sustainable performance of an enterprise dramatically. 
DOI: 10.14807/ijmp.v12i1.1238

From another aspect and according to the results, the way of achieving strategic sustainability orientation passes from managers' and employees' attitudes meaning that if they believe in sustainability development it will be possible. It seems that activities which change their minds should be developed by the Iranian government but these activities should not be implemented by pressure because as it is found that mimetic pressures are not useful drivers in Iran.

It seems that educational programs for employees and managers should be the most applicable way. On the other hand, although the majority of previous research, such as (Delmas \& Toffel, 2004; Kudłak, 2017; Liu et al., 2010; Roehrich et al., 2017; Tachizawa et al., 2015; Teo et al., 2003) came into conclusion that factors, such as competitors, governmental regulations, customers, supply chain suppliers and generally the society assist the organizations to execute sustainability strategies, our results manifest that the hypotheses asserting that Mimetic, Coercive and Normative pressures have positive impacts on strategic sustainability orientation are not supported and actually there are no relationships between these variables.

It shows that some of the governmental policies in Iran have not been applicable and coercive pressures should be improved by the government and much more control is required to be imposed. A. Emamisaleh et al. (2012) presented that private projects in Iran are more efficient than governmental projects. It is worth mentioning that mimetic and normative pressures are not efficient derivers for Iranian companies since the majority of them run the production process without paying attention to their competitors especially when they want to implement a new quality assurance system.

In the second phase of research conceptual model, the relationship between strategic sustainability orientation and firm operational performance by considering corporate environmental management and corporate social responsibility as mediating factors is examined.

The results indicate that strategic sustainability orientation with the mediating role of corporate environmental management and corporate social responsibility has a positive impact on firm performance. It means that corporate social responsibility and corporate environmental management play a vital role to improve firm performance. Besides, based on the study of Emamisaleh, Rahmani and Iranzadeh (2018), sustainable operations management practices, including quality management, corporate environmental management, and corporate social 
DOI: 10.14807/ijmp.v12i1.1238

responsibility have positive effects on the economic, environmental and social performance of food industry companies of Iran.

Moreover, other studies confirm that there is a positive relationship between corporate social responsibility and firm performance which is one of the main results of the current paper (Agyemang \& Ansong, 2017; Makanyeza et al., 2018; Maqbool \& Zameer, 2018). Additionally, in accordance with previous studies, such as Nishitani et al., (2017) and Solovida and Latan, (2017) we have concluded that corporate environmental management practices affect firm performance in a positive way.

\subsection{Conclusion}

In this paper, the initiatives and the consequences of sustainable supply chain management by emphasizing on strategic sustainability orientation are studied. According to the results, while there are no relationships between the mimetic, coercive and normative pressures and strategic sustainability orientation variable, other drivers involving managerial attitude and employees' motivation impact it positively.

Accordingly and having reconsidered the definitions of sustainability orientation as "the extent to which firms are actively integrating sustainability principles into their business purpose" and "the overall proactive strategic stance of firms towards the integration of environmental and social concerns and practices into their strategic, tactical and operational activities” submitted by Claudy et al., (2016) and Roxas and Coetzer, (2012), it is obvious that sustainability orientation is mostly related to the internal organizational structures, such as strategic and cultural structures.

In other words, managers not only should be optimistic about sustainability issues but also employees should have a positive tendency towards them in order to have sustainability strategies implemented successfully. Therefore, we can conclude that when we are studying the sustainable supply chain management drivers from the perspective of strategic sustainability orientation, managers' support and attitude, as well as employees' motivation drivers, should be taken into high considerations since, in this regard, we are more focused on internal organizational procedures than external ones.

On the other hand, based on the results of this study, among the various practices of sustainable supply chain management, corporate social responsibility, and corporate environmental management practices have shown that when they are amalgamated with the 
INDEPENDENT JOURNAL OF MANAGEMENT \& PRODUCTION (IJM\&P)

http://www.ijmp.jor.br

v. 12, n. 1, January-February 2021

ISSN: 2236-269X

DOI: 10.14807/ijmp.v12i1.1238

strategies of a company through executing the sustainability issues, positive impacts on firm operational performance are expected.

\section{REFERENCE}

Agyemang, O. S., \& Ansong, A. (2017). Corporate social responsibility and firm performance of Ghanaian SMEs. Journal of Global Responsibility.

https://doi.org/10.1108/JGR-03-2016-0007

Ahmad, S., Wong, K. Y., Tseng, M. L., \& Wong, W. P. (2018). Sustainable product design and development: A review of tools, applications and research prospects. Resources, Conservation and Recycling, 132, 49-61. https://doi.org/10.1016/j.resconrec.2018.01.020

Allen, D., Bauer, D., Bras, B., Gutowski, T., Murphy, C., Piwonka, T., ... Wolff, E. (2002). Environmentally Benign Manufacturing: Trends in Europe, Japan, and the USA. Journal of Manufacturing Science and Engineering, 124(4), 908-920.

https://doi.org/10.1115/1.1505855

Amini, C., \& Bianco, S. D. (2017). Corporate social responsibility and Latin American firm performance. Corporate Governance: The International Journal of Business in Society. https://doi.org/10.1108/CG-03-2016-0060

Ann, G. E., Zailani, S., \& Wahid, N. A. (2006). A study on the impact of environmental management system (EMS) certification towards firms’ performance in Malaysia.

Management of Environmental Quality: An International Journal.

https://doi.org/10.1108/14777830610639459

Aragón-Correa, J. A., \& Sharma, S. (2003). A Contingent Resource-Based View of Proactive Corporate Environmental Strategy. The Academy of Management Review, 28(1), 71-88. https://doi.org/10.2307/30040690

Banerjee, S. B. (2002). Corporate environmentalism: The construct and its measurement. Journal of Business Research, 55(3), 177-191. https://doi.org/10.1016/S01482963(00)00135-1

Bansal, P. (2005). Evolving sustainably: A longitudinal study of corporate sustainable development. Strategic Management Journal, 26(3), 197-218.

https://doi.org/10.1002/smj.441

Baumgartner, R. J. (2010). Sustainability-oriented corporate governance: Model, strategies and management (1st ed.). Rainer Hampp Verlag.

Baumgartner, R. J., \& Rauter, R. (2017). Strategic perspectives of corporate sustainability management to develop a sustainable organization. Journal of Cleaner Production, 140, 81-92. https://doi.org/10.1016/j.jclepro.2016.04.146

Berry, M. A., \& Rondinelli, D. A. (1998). Proactive corporate environmental management: A new industrial revolution. Academy of Management Perspectives, 12(2), 38-50.

https://doi.org/10.5465/ame.1998.650515

Beske, P., Land, A., \& Seuring, S. (2014). Sustainable supply chain management practices and dynamic capabilities in the food industry: A critical analysis of the literature.

International Journal of Production Economics, 152, 131-143.

https://doi.org/10.1016/j.ijpe.2013.12.026

Bloemhof-Ruwaard, J. M., Van Wassenhove, L. N., Gabel, H. L., \& Weaver, P. M. (1996). 
An environmental life cycle optimization model for the European pulp and paper industry. Omega, 24(6), 615-629. https://doi.org/10.1016/S0305-0483(96)00026-6

Bowen, H. R. (1953). Social responsibilities of the businessman; New York: Harper.

Burgos-Jiménez, J. de, Vázquez-Brust, D., Plaza-Úbeda, J. A., \& Dijkshoorn, J. (2013). Environmental protection and financial performance: An empirical analysis in Wales. International Journal of Operations \& Production Management. https://doi.org/10.1108/IJOPM-11-2010-0374

Campbell, D. J. (2000). Legitimacy Theory or Managerial Reality Construction? Corporate Social Disclosure in Marks and Spencer Plc Corporate Reports, 1969-1997. Accounting Forum, 24(1), 80-100. https://doi.org/10.1111/1467-6303.00030

Caniato, F., Caridi, M., Crippa, L., \& Moretto, A. (2012). Environmental sustainability in fashion supply chains: An exploratory case based research. International Journal of Production Economics, 135(2), 659-670. https://doi.org/10.1016/j.ijpe.2011.06.001

Chan, R. Y. K., He, H., Chan, H. K., \& Wang, W. Y. C. (2012). Environmental orientation and corporate performance: The mediation mechanism of green supply chain management and moderating effect of competitive intensity. Industrial Marketing Management, 41(4), 621-630. https://doi.org/10.1016/j.indmarman.2012.04.009

Christmann, P. (2000). Effects of “Best Practices” of Environmental Management on Cost Advantage: The Role of Complementary Assets. The Academy of Management Journal, 43(4), 663-680. https://doi.org/10.2307/1556360

Claudy, M. C., Peterson, M., \& Pagell, M. (2016). The Roles of Sustainability Orientation and Market Knowledge Competence in New Product Development Success. Journal of Product Innovation Management, 33(S1), 72-85. https://doi.org/10.1111/jpim.12343

Croom, S., Vidal, N., Spetic, W., Marshall, D., \& McCarthy, L. (2018). Impact of social sustainability orientation and supply chain practices on operational performance.

International Journal of Operations \& Production Management.

https://doi.org/10.1108/IJOPM-03-2017-0180

Dahlsrud, A. (2008). How corporate social responsibility is defined: An analysis of 37 definitions. Corporate Social Responsibility and Environmental Management, 15(1), 1 13. https://doi.org/10.1002/csr.132

Daily, B. F., \& Huang, S. (2001). Achieving sustainability through attention to human resource factors in environmental management. International Journal of Operations \& Production Management. https://doi.org/10.1108/01443570110410892

Danso, A., Adomako, S., Amankwah-Amoah, J., Owusu-Agyei, S., \& Konadu, R. (2019). Environmental sustainability orientation, competitive strategy and financial performance. Business Strategy and the Environment, 28(5), 885-895. https://doi.org/10.1002/bse.2291

Defee, C. C., Esper, T., \& Mollenkopf, D. (2009). Leveraging closed-loop orientation and leadership for environmental sustainability. Supply Chain Management: An International Journal. https://doi.org/10.1108/13598540910941957

Delmas, M., \& Toffel, M. W. (2004). Stakeholders and environmental management practices: An institutional framework. Business Strategy and the Environment, 13(4), 209-222. https://doi.org/10.1002/bse.409

DiMaggio, P. J., \& Powell, W. W. (1983). The Iron Cage Revisited: Institutional Isomorphism and Collective Rationality in Organizational Fields. American Sociological 
INDEPENDENT JOURNAL OF MANAGEMENT \& PRODUCTION (IJM\&P)

http://www.ijmp.jor.br

v. 12, n. 1, January-February 2021

ISSN: 2236-269X

DOI: 10.14807/ijmp.v12i1.1238

Review, 48(2), 147-160. https://doi.org/10.2307/2095101

Dyllick, T., \& Hockerts, K. (2002). Beyond the business case for corporate sustainability.

Business Strategy and the Environment, 11(2), 130-141. https://doi.org/10.1002/bse.323

Eijdenberg, E. L., Sabokwigina, D., \& Masurel, E. (2019). Performance and environmental sustainability orientations in the informal economy of a least developed country.

International Journal of Entrepreneurial Behavior \& Research.

https://doi.org/10.1108/IJEBR-01-2018-0040

Elkington, J. (1994). Towards the Sustainable Corporation: Win-Win-Win Business

Strategies for Sustainable Development. California Management Review, 36(2), 90-100. https://doi.org/10.2307/41165746

Elkington, J. (1999). Cannibals With Forks: Triple Bottom Line of 21st Century Business. Oxford: John Wiley \& Son Ltd.

Emamisaleh, A., Yavari, A., Maleki, M., \& Mohammadi Alamouto, S. (2012). Ranking of efficient approaches to urban infrastructures management by using TOPSIS method: Case study of Iran. Recent Researches in Engineering Mechanics, Urban \& Naval Transportation and Tourism, 252-257.

Emamisaleh, K., \& Rahmani, K. (2017). Sustainable supply chain in food industries: Drivers and strategic sustainability orientation. Cogent Business \& Management, 4(1), 1345296. https://doi.org/10.1080/23311975.2017.1345296

Emamisaleh, K., Rahmani, K., \& Iranzadeh, S. (2018). Sustainable Supply Chain Management Practices and Sustainability Performance in the Food Industry. The South East Asian Journal of Management. https://doi.org/10.21002/seam.v12i1.8689

Engert, S., Rauter, R., \& Baumgartner, R. J. (2016). Exploring the integration of corporate sustainability into strategic management: A literature review. Journal of Cleaner Production, 112, 2833-2850. https://doi.org/10.1016/j.jclepro.2015.08.031

Fraj-Andrés, E., Martinez-Salinas, E., \& Matute-Vallejo, J. (2008). A Multidimensional Approach to the Influence of Environmental Marketing and Orientation on the Firm's Organizational Performance. Journal of Business Ethics, 88(2), 263.

https://doi.org/10.1007/s10551-008-9962-2

Gimenez, C., Sierra, V., \& Rodon, J. (2012). Sustainable operations: Their impact on the triple bottom line. International Journal of Production Economics, 140(1), 149-159. https://doi.org/10.1016/j.ijpe.2012.01.035

Goodland, R. (1995). The concept of environmental sustainability. Annual Review of Ecology and Systematics, 26(1), 1-24.

https://doi.org/10.1146/annurev.es.26.110195.000245

Gray, R., \& Bebbington, J. (2001). Accounting for the Environment (2nd ed.). https://doi.org/10.4135/9781446220849

Green, K. W., Zelbst, P. J., Meacham, J., \& Bhadauria, V. S. (2012). Green supply chain management practices: Impact on performance. Supply Chain Management: An

International Journal. https://doi.org/10.1108/13598541211227126

Guide, V. D. R. (2000). Production planning and control for remanufacturing: Industry practice and research needs. Journal of Operations Management, 18(4), 467-483. https://doi.org/10.1016/S0272-6963(00)00034-6

Haapala, K. R., Zhao, F., Camelio, J., Sutherland, J. W., Skerlos, S. J., Dornfeld, D. A., ... 
Rickli, J. L. (2013). A Review of Engineering Research in Sustainable Manufacturing. Journal of Manufacturing Science and Engineering, 135(4), 041013-041013-041016. https://doi.org/10.1115/1.4024040

Hanna, M. D., Newman, W. R., \& Johnson, P. (2000). Linking operational and environmental improvement through employee involvement. International Journal of Operations \& Production Management. https://doi.org/10.1108/01443570010304233

Harris, L. C., \& Crane, A. (2002). The greening of organizational culture: Management views on the depth, degree and diffusion of change. Journal of Organizational Change Management, 15(3), 214-234. https://doi.org/10.1108/09534810210429273

Hassini, E., Surti, C., \& Searcy, C. (2012). A literature review and a case study of sustainable supply chains with a focus on metrics. International Journal of Production Economics, 140(1), 69-82. https://doi.org/10.1016/j.ijpe.2012.01.042

Holme, R., Watts, P., \& World Business Council for Sustainable Development. (2000).

Corporate social responsibility: Making good business sense. Conches-Geneva, Switzerland: World Business Council for Sustainable Development.

Hsu, C.-C., Tan, K. C., Zailani, S. H. M., \& Jayaraman, V. (2013). Supply chain drivers that foster the development of green initiatives in an emerging economy. International Journal of Operations \& Production Management. https://doi.org/10.1108/IJOPM-10-2011-0401

Iwata, H., \& Okada, K. (2011). How does environmental performance affect financial performance? Evidence from Japanese manufacturing firms. Ecological Economics, 70(9), 1691-1700. https://doi.org/10.1016/j.ecolecon.2011.05.010

Janamrung, B., \& Issarawornrawanich, P. (2015). The association between corporate social responsibility index and performance of firms in industrial products and resources industries: Empirical evidence from Thailand. Social Responsibility Journal. https://doi.org/10.1108/SRJ-11-2013-0141

Jia, F., Zuluaga-Cardona, L., Bailey, A., \& Rueda, X. (2018). Sustainable supply chain management in developing countries: An analysis of the literature. Journal of Cleaner Production, 189, 263-278. https://doi.org/10.1016/j.jclepro.2018.03.248

Jin, Z., Navare, J., \& Lynch, R. (2018). The relationship between innovation culture and innovation outcomes: Exploring the effects of sustainability orientation and firm size. R\&D Management, 0(0). https://doi.org/10.1111/radm.12351

Karakayali, I., Emir-Farinas, H., \& Akcali, E. (2007). An analysis of decentralized collection and processing of end-of-life products. Journal of Operations Management, 25(6), 11611183. https://doi.org/10.1016/j.jom.2007.01.017

Kim, D., \& Kim, S. (2019). An institutional analysis of environmental management in the Korean mobile communications industry. Telecommunications Policy. https://doi.org/10.1016/j.telpol.2019.03.004

Klassen, R. D., \& McLaughlin, C. P. (1996). The Impact of Environmental Management on Firm Performance. Management Science, 42(8), 1199-1214.

https://doi.org/10.1287/mnsc.42.8.1199

Köksal, D., Strähle, J., Müller, M., \& Freise, M. (2017). Social Sustainable Supply Chain Management in the Textile and Apparel Industry-A Literature Review. Sustainability, 9(1), 100. https://doi.org/10.3390/su9010100

Koo, C., Chung, N., \& Ryoo, S. Y. (2014). How does ecological responsibility affect 
DOI: 10.14807/ijmp.v12i1.1238

manufacturing firms’ environmental and economic performance? Total Quality Management \& Business Excellence, 25(9-10), 1171-1189.

https://doi.org/10.1080/14783363.2013.835615

Kristal, M. M., Huang, X., \& Roth, A. V. (2010). The effect of an ambidextrous supply chain strategy on combinative competitive capabilities and business performance. Journal of Operations Management, 28(5), 415-429. https://doi.org/10.1016/j.jom.2009.12.002

Kroes, J. R., \& Ghosh, S. (2010). Outsourcing congruence with competitive priorities: Impact on supply chain and firm performance. Journal of Operations Management, 28(2), 124143. https://doi.org/10.1016/j.jom.2009.09.004

Kudłak, R. (2017). Drivers of corporate environmentalism: The case of the Polish economy in transition. Journal of Cleaner Production, 142, 3194-3203.

https://doi.org/10.1016/j.jclepro.2016.10.150

Laudal, T. (2011). Determinants and impacts of Corporate Social Responsibility: A market centric approach. Retrieved from https://uis.brage.unit.no/uisxmlui/handle/11250/184954

Lee, S.-Y. (2008). Drivers for the participation of small and medium-sized suppliers in green supply chain initiatives. Supply Chain Management: An International Journal. https://doi.org/10.1108/13598540810871235

Linke, B. S., Corman, G. J., Dornfeld, D. A., \& Tönissen, S. (2013). Sustainability indicators for discrete manufacturing processes applied to grinding technology. Journal of Manufacturing Systems, 32(4), 556-563. https://doi.org/10.1016/j.jmsy.2013.05.005

Liu, H., Ke, W., Wei, K. K., Gu, J., \& Chen, H. (2010). The role of institutional pressures and organizational culture in the firm's intention to adopt internet-enabled supply chain management systems. Journal of Operations Management, 28(5), 372-384. https://doi.org/10.1016/j.jom.2009.11.010

Liu, M., \& Lu, W. (2019). Corporate social responsibility, firm performance, and firm risk: The role of firm reputation. Asia-Pacific Journal of Accounting \& Economics, 0(0), 1-21. https://doi.org/10.1080/16081625.2019.1601022

Makanyeza, C., Chitambara, T. L., \& Kakava, N. Z. (2018). Does Corporate Social Responsibility Influence Firm Performance? Empirical Evidence from Harare, Zimbabwe. Journal of African Business, 19(2), 155-173.

https://doi.org/10.1080/15228916.2017.1410047

Maqbool, S., \& Zameer, M. N. (2018). Corporate social responsibility and financial performance: An empirical analysis of Indian banks. Future Business Journal, 4(1), 84-93. https://doi.org/10.1016/j.fbj.2017.12.002

Martinez-Conesa, I., Soto-Acosta, P., \& Palacios-Manzano, M. (2017). Corporate social responsibility and its effect on innovation and firm performance: An empirical research in SMEs. Journal of Cleaner Production, 142, 2374-2383. https://doi.org/10.1016/j.jclepro.2016.11.038

McFadden, K. L., Henagan, S. C., \& Gowen, C. R. (2009). The patient safety chain: Transformational leadership's effect on patient safety culture, initiatives, and outcomes. Journal of Operations Management, 27(5), 390-404. https://doi.org/10.1016/j.jom.2009.01.001

McWilliams, A., Siegel, D. S., \& Wright, P. M. (2006). Corporate Social Responsibility: 
Strategic Implications*. Journal of Management Studies, 43(1), 1-18. https://doi.org/10.1111/j.1467-6486.2006.00580.x

Mohanty, R. p., \& Prakash, A. (2017). Searching for definitions and boundaries in sustainable production system. International Journal of Services and Operations Management, 27(1), 122-143. https://doi.org/10.1504/IJSOM.2017.083339

Nikolaou, E. I., Ierapetritis, D., \& Tsagarakis, K. P. (2011). An evaluation of the prospects of green entrepreneurship development using a SWOT analysis. International Journal of Sustainable Development \& World Ecology, 18(1), 1-16.

https://doi.org/10.1080/13504509.2011.543565

Nishitani, K., Jannah, N., Kaneko, S., \& Hardinsyah. (2017). Does corporate environmental performance enhance financial performance? An empirical study of indonesian firms.

Environmental Development, 23, 10-21. https://doi.org/10.1016/j.envdev.2017.06.003

North, K. (1997). Environmental Business Management: An Introduction. International Labour Organization.

Pagell, M., \& Wu, Z. (2009). Building a More Complete Theory of Sustainable Supply Chain Management Using Case Studies of 10 Exemplars. Journal of Supply Chain Management, 45(2), 37-56. https://doi.org/10.1111/j.1745-493X.2009.03162.x

Porter, M. E., \& van der Linde, C. (1995). Toward a New Conception of the EnvironmentCompetitiveness Relationship. Journal of Economic Perspectives, 9(4), 97-118. https://doi.org/10.1257/jep.9.4.97

Reed, K. E. (2002a). Everyone Takes the Field: How 3M Encourages Employee Involvement in Promoting Sustainable Development. Corporate Environmental Strategy, 9(4), 383389. https://doi.org/10.1016/S1066-7938(02)00109-4

Reed, K. E. (2002b). Everyone Takes the Field: How 3M Encourages Employee Involvement in Promoting Sustainable Development. Corporate Environmental Strategy, 9(4), 383389. https://doi.org/10.1016/S1066-7938(02)00109-4

Resource-based view. (2019). In Wikipedia. Retrieved from https://en.wikipedia.org/w/index.php?title=Resource-based_view\&oldid=901347237

Robins, F. (2005). The Future of Corporate Social Responsibility. Asian Business \& Management, 4(2), 95-115. https://doi.org/10.1057/palgrave.abm.9200125

Roehrich, J. K., Hoejmose, S. U., \& Overland, V. (2017). Driving green supply chain management performance through supplier selection and value internalisation. International Journal of Operations \& Production Management. https://doi.org/10.1108/IJOPM-092015-0566

Roxas, B., \& Coetzer, A. (2012). Institutional Environment, Managerial Attitudes and Environmental Sustainability Orientation of Small Firms. Journal of Business Ethics, 111(4), 461-476. https://doi.org/10.1007/s10551-012-1211-z

Sayem, M. (2012). Sustainability Orientation: Driver of Firms’ Innovativeness and Business Performance (SSRN Scholarly Paper No. ID 2157891). Retrieved from Social Science Research Network website: https://papers.ssrn.com/abstract=2157891

Schwartz, M. S., \& Carroll, A. B. (2003). Corporate Social Responsibility: A Three-Domain Approach. Business Ethics Quarterly, 13(4), 503-530. Retrieved from JSTOR.

Seuring, S., \& Müller, M. (2008). From a literature review to a conceptual framework for sustainable supply chain management. Journal of Cleaner Production, 16(15), 1699-1710. 
DOI: 10.14807/ijmp.v12i1.1238

https://doi.org/10.1016/j.jclepro.2008.04.020

Sharma, S. (2000). Managerial Interpretations and Organizational Context as Predictors of Corporate Choice of Environmental Strategy. The Academy of Management Journal, 43(4), 681-697. https://doi.org/10.2307/1556361

Shashi, S., Cerchione, R., Centobelli, P., \& Shabani, A. (2018). Sustainability orientation, supply chain integration, and SMEs performance: A causal analysis. Benchmarking: An International Journal. https://doi.org/10.1108/BIJ-08-2017-0236

Shrivastava, P., \& Berger, S. (2010). Sustainability principles: A review and directions. Organization Management Journal, 7(4), 246-261. https://doi.org/10.1057/omj.2010.35

Sial, M. S., Chunmei, Z., Khan, T., \& Nguyen, V. K. (2018). Corporate social responsibility, firm performance and the moderating effect of earnings management in Chinese firms. AsiaPacific Journal of Business Administration. https://doi.org/10.1108/APJBA-03-2018-0051

Signori, P., Flint, D. J., \& Golicic, S. (2015). Toward sustainable supply chain orientation (SSCO): Mapping managerial perspectives. International Journal of Physical Distribution \& Logistics Management. https://doi.org/10.1108/IJPDLM-07-2014-0160

Solovida, G. T., \& Latan, H. (2017). Linking environmental strategy to environmental performance. Sustainability Accounting, Management and Policy Journal. https://doi.org/10.1108/SAMPJ-08-2016-0046

Tachizawa, E. M., Gimenez, C., \& Sierra, V. (2015). Green supply chain management approaches: Drivers and performance implications. International Journal of Operations \& Production Management. https://doi.org/10.1108/IJOPM-01-2015-0023

Teo, H. H., Wei, K. K., \& Benbasat, I. (2003). Predicting Intention to Adopt Interorganizational Linkages: An Institutional Perspective. MIS Quarterly, 27(1), 19-49. https://doi.org/10.2307/30036518

Tilman, D., Cassman, K. G., Matson, P. A., Naylor, R., \& Polasky, S. (2002). Agricultural sustainability and intensive production practices. Nature, 418(6898), 671.

https://doi.org/10.1038/nature01014

Varsei, M., Soosay, C., Fahimnia, B., \& Sarkis, J. (2014). Framing sustainability performance of supply chains with multidimensional indicators. Supply Chain Management: An

International Journal. https://doi.org/10.1108/SCM-12-2013-0436

Veleva, V., \& Ellenbecker, M. (2001). Indicators of sustainable production: Framework and methodology. Journal of Cleaner Production, 9(6), 519-549.

https://doi.org/10.1016/S0959-6526(01)00010-5

Waas, T., Hugé, J., Block, T., Wright, T., Benitez-Capistros, F., \& Verbruggen, A. (2014).

Sustainability Assessment and Indicators: Tools in a Decision-Making Strategy for

Sustainable Development. Sustainability, 6(9), 5512-5534.

https://doi.org/10.3390/su6095512

Wang, Y. G., Hsu, W.-H. L., \& Chang, K.-W. (2012). The Impact of Fulfilling Corporate Social Responsibility on Firm Performance-A Stakeholder's Approach. International Journal of Modelling and Simulation, 32(3), 206-215.

https://doi.org/10.2316/Journal.205.2012.3.205-5731

World Commission on Environment and Development. (1987). Our common future. Oxford; New York: Oxford University Press.

Wu, H., Lv, K., Liang, L., \& Hu, H. (2017). Measuring performance of sustainable 
ISSN: 2236-269X

DOI: 10.14807/ijmp.v12i1.1238

manufacturing with recyclable wastes: A case from China's iron and steel industry. Omega, 66, 38-47. https://doi.org/10.1016/j.omega.2016.01.009

Xie, Y., \& Allen, C. (2013). Information technologies in retail supply chains: A comparison of Tesco and Asda. International Journal of Business Performance and Supply Chain Modelling, 5(1), 46-62. https://doi.org/10.1504/IJBPSCM.2013.051648

Youn, H., Hua, N., \& Lee, S. (2015). Does size matter? Corporate social responsibility and firm performance in the restaurant industry. International Journal of Hospitality Management, 51, 127-134. https://doi.org/10.1016/j.ijhm.2015.09.008

Zhu, Q., \& Sarkis, J. (2006). An inter-sectoral comparison of green supply chain management in China: Drivers and practices. Journal of Cleaner Production, 4(5), 472-486.

https://doi.org/10.1016/j.jclepro.2005.01.003 